The $2{ }^{\text {nd }}$ Conf. of SSFOP "Future of Ornamental Plants in Egypt and Arab World", Cairo, Egypt, 21/2/2016

Scientific J. Flowers \& Ornamental Plants

www.ssfop.com/journal

ISSN: 2356-7864

\title{
EFFECT OF FYM, MINIA AZOTEIN, SALICYLIC AND ASCORBIC ACIDS TREATMENTS ON GROWTH AND ESSENTIAL OIL PRODUCTION OF CORIANDER (CORIANDRUM SATIVUM, L.) PLANTS
}

\author{
M.A.H. Abdou ${ }^{*}$ and T.I.E. Ibrahim ${ }^{* *}$ \\ * Hort. Dept., Fac. Agric., Minia Univ., Egypt. \\ ** Ministry of Agriculture, Egypt.
}

ABSTRACT: A field experiment was carried out during 2013/2014 and 2014/2015 seasons at the Experimental Farm, Fac. of Agric., Minia Univ. to investigate the effect of FYM (0, 10, 15 and 20 ton/fed), Minia Azotein (M.A.) as biofertilizer containing $\mathrm{N}$-fixing bacteria, salicylic acid (Sal.), ascorbic acid (Asc.), M.A. + Sal. and

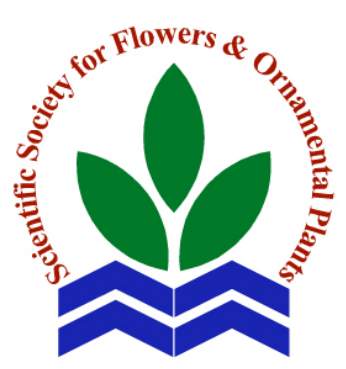

Scientific J. Flowers \& Ornamental Plants, 3(1):37-44 (2016).

Received:

16/1/2016

Revised by:

Prof. Dr. M.K. Abd El-Aal, Minia Univ.

Prof. Dr. Shadia K. Ahmed, Hort. Res. Inst., ARC. M.A. + Asc. on the vegetative growth and essential oil productivity of coriander plants.

The obtained data revealed that vegetative growth characters (plant height, number of branches/plant and herb dry weight/plant) and essential oil production (oil \% as well as oil yield/plant and /fed) were significantly increased due to the application of all levels of FYM over those of control treatment. The maximum values were recorded at the high level of FYM (20 ton/fed). Vegetative growth characters and essential oil productivity parameters were significantly augmented as a result of using the different five treatments. The most effective treatments in this concern were Minia Azotein (M.A.) + salicylic acid (at $50 \mathrm{ppm}$ ) followed by Minia Azotein (M.A.) + ascorbic acid (at 50 ppm) without significant difference between such superior treatments. While, M.A. plus either salicylic acid or ascorbic acid gave the highest essential oil \% and oil yield /plant and /fed.

It could be recommended to supply Coriandrum sativum plants with FYM at 20 ton/fed in combination with M.A. + salicylic acid or ascorbic acid each at $50 \mathrm{ppm}$ to give the high productivity and the safety, not only for human but also for the environment in which we live.

Key words: Coriandrum sativum, FYM, Minia Azotein, biofertilizer containing $\mathrm{N}$-fixing bacteria, salicylic acid, ascorbic acid.

\section{INTRODUCTION}

Coriander (Coriandrum sativum) belongs to the Apiaceae family. It is herbaceous annual plant, which is native to Mediterranean region. The coriander seeds have essential oil as an active substance, while linalool and pinene are the most important constituents of coriander oil which are used in pharmaceutical, food, perfumery and flavoring industry (Stary and Jirasck, 1975).

Organic material improve soil physical and chemical properties that important for plant growth and improved the volatile oil (Osman, 2000; Khattab and Gomaa, 2004; 
Abdalla, 2009 and Rekaby, 2013) on coriander, (Abdou et al., 2014) on khilla and (Ismail, 2008 and Shoor et al., 2010) on black cumin.

Minia Azotein (M.A.) as biofertilizer (contains $\mathrm{N}$-fixing bacteria) had positive effect on growth and essential oil production namely (Helmy, 2008) on black cumin, (Hemdan, 2008) on anise, (Abdou et al., 2012) on sage and (Abd El-Latif, 2014) on lavender.

Ascorbic acid and Salicylic acid have synergistic effect on growth and productivity of most medical and aromatic plants as follows. Al-Shareif (2006) and Botros (2013) on caraway, Ayat (2007) and Rekaby (2013) on coriander, Tanious (2008) and Hendawy and Ezz El-Din (2010) on fennel. They showed that foliar spray of ascorbic acid increased growth and essential oil \% and yield.

While, Ismail (2008) on black cumin, Abdou et al. (2009b), Shala (2012) and Botros (2013) on caraway, Hassan and Ali (2010) and Rekaby (2013) on coriander and Al-Shewailly (2012) and Rahimi et al. (2013) on cumin. They found that salicylic acid treatments increased all vegetative growth parameters and essential oil \% and essential oil yield/plant.

Production of medicinal and aromatic plants using organic matter, biofertilizer (M.A.), salicylic and ascorbic acids became an essential process to ensure the safety, not only for human, but also for the environment in which we live. So, the present study was carried out to investigate the effect of FYM, Minia Azotein and salicylic and ascorbic acids on growth and oil production of coriander plants.

\section{MATERIALS AND METHODS}

Field experiment was carried out during the two successive seasons of $2013 / 2014$ and 2014/2015 at the Nursery and Laboratory, Fac. of Agric. Minia Univ. Seeds of coriander plants were sown on September $25^{\text {th }}$ for both seasons, in $2.1 \times 2.1 \mathrm{~m}$ plots with
$70 \mathrm{~cm}$ distance between the rows and $30 \mathrm{~cm}$ between hills within each raw. So, each plot contained 3 rows and 21 hills, each hill contained 2 plants. Physical and chemical characters of the used soil are shown in Table (a).

Plants were thinned twice, the first one after one month from planting date and the second one after two weeks from the first one. All other agricultural practices were followed as usual.

A complete randomized block design following the split plot arrangement, in three replicates, was executed in this experiment with four Farmyard manure (FYM) treatments $(0,10,15$ and 20 ton/fed) in the main plots and five treatments [Minia Azotein (M.A.), salicylic acid (Sal.) at 50 ppm, ascorbic acid (Asc.) at 50 ppm, M.A. + Sal. and M.A. + Asc.] in the sub plots. Farmyard manure (FYM) amounts, for each treatment, were added to the soil during preparation. Physical and chemical properties of the Farmyard manure (FYM) are shown in Table (b).

M.A. was applied three times to the soil beside the plants at $50 \mathrm{ml} /$ hill while, salicylic and ascorbic acids each at $50 \mathrm{ppm}$ were applied by hand sprayer three times. The first dose (for M.A., Sal. and Asc.) was added after 50 days from planting date and the $2^{\text {nd }}$ and $3^{\text {rd }}$ spray were done at one month thereafter.

At the end of experiment (first week of May), the following data were recorded:

- Vegetative growth characters: Plant height $(\mathrm{cm})$, number of branches/plant and herb dry weight/plant (g).

- Essential oil determination: Essential oil \%, oil yield/plant $(\mathrm{ml})$ and $/$ fed (liter) were calculated.

The obtained data were tabulated and statistically analyzed according to MSTATC (1986) and L.S.D. test at 5\% was followed to compare between the means. 
Table a. Physical and chemical properties of the used soil.

\begin{tabular}{|c|c|c|c|c|}
\hline Soil Character & Value & \multicolumn{2}{|c|}{ Soil Character } & Value \\
\hline Sand $\%$ & 28.30 & \multicolumn{2}{|c|}{ Available P \% } & 15.12 \\
\hline Silt \% & 30.70 & \multicolumn{2}{|c|}{ Exch. $\mathrm{K}^{+}$(mg/100 g soil) } & 2.11 \\
\hline Clay \% & 41.00 & \multicolumn{2}{|c|}{ Exch. $\mathrm{Ca}^{++}(\mathrm{mg} / 100 \mathrm{~g}$ soil $)$} & 31.74 \\
\hline Soil type & Clay loam & \multicolumn{2}{|c|}{ Exch. $\mathrm{Na}^{+}$(mg/100 g soil) } & 2.41 \\
\hline Organic matter \% & 1.62 & \multirow{5}{*}{$\begin{array}{l}\text { DTPA } \\
\text { Ext. ppm }\end{array}$} & $\mathbf{F e}$ & 8.54 \\
\hline $\mathrm{CaCO}_{3} \%$ & 2.09 & & $\mathbf{C u}$ & 2.06 \\
\hline pH (1:2.5) & 7.83 & & $\mathbf{Z n}$ & 2.75 \\
\hline E.C. $(\mathrm{mmhos} / \mathrm{cm})$ & 1.04 & & Mn & 8.26 \\
\hline Total N \% & 0.08 & & & \\
\hline
\end{tabular}

Table b. Physical and chemical properties of the used Farmyard manure (FYM).

\begin{tabular}{lclc}
\hline Content & Value & Content & Value \\
\hline Organic matter (\%) & 27.07 & $\mathrm{~K}(\%)$ & 1.09 \\
Carbon (\%) & 15.70 & $\mathrm{Fe} \mathrm{(ppm)}$ & 2379.2 \\
Total N (\%) & 0.82 & $\mathrm{Zn}(\mathrm{ppm})$ & 274.2 \\
C/N ratio & 19.14 & $\mathrm{Mn}(\mathrm{ppm})$ & 235.4 \\
Humidity & 8.01 & $\mathrm{pH}$ & 7.44 \\
$\mathrm{P}(\%)$ & 0.25 & E.C. $(\mathrm{m}$. mhose/cm) & 1.08 \\
\hline
\end{tabular}

\section{RESULTS}

\section{1- Vegetative growth parameters:}

Data presented in Table (1) indicate that, the three levels of FYM had significantly positive effect on vegetative growth characters i.e. plant height, number of branches and herb dry weight/plant compared with control. Data also showed that, FYM at 20 ton/fed gave the maximum mean values of plant height (121.51 and $127.20 \mathrm{~cm}$ ), number of branches (9.50 and 9.37) and herb dry weight/plant (56.97 and $56.39 \mathrm{~g})$ for both seasons, respectively compared to control. Obtained results agreed with those of Rekaby (2013) on coriander and Ibrahim (2014) on khilla plants.

Also, the obtained results indicated that all used treatments of Minia Azotein (M.A.) and/or salicylic acid or ascorbic acid had remarkably positive effect on vegetative growth characters (plant height, number of branches/plant and herb dry weight/plant).
The treatments of M.A. + Sal. followed by M.A. + Asc. resulted the best values of vegetative growth comparing with other used treatments in both seasons (Table, 1). M.A. had positive effect on vegetative growth parameters as reported by Abdou et al. (2009a) on borage and Ibrahim (2014) on khilla plants.

Also, salicylic acid increased plant growth characters as mentioned by Ismail (2008) on black cumin and Abdou et al. (2013) on caraway. Ascorbic acid as an antioxidant increased vegetative growth characters as mentioned by Al-Shareif (2006) and Botros (2013) on caraway, Ayat (2007) and Rekaby (2013) on coriander, Tanious (2008) and Hendawy and Ezz ElDin (2010) on fennel.

The interaction between the two studied factors $(\mathrm{A} \times \mathrm{B})$ was significant for plant height, number of branches and herb dry weight/plant (Table, 1). The highest values were obtained due to addition FYM at 20 
Table 1. Effect of FYM, Minia Azotein, salicylic acid and ascorbic acid on plant height (cm), number of branches/plant and herb dry weight/plant (g) of coriander (Coriandrum sativum, L.) plants, during the first and second seasons.

\begin{tabular}{|c|c|c|c|c|c|c|c|c|c|c|}
\hline \multirow{3}{*}{$\begin{array}{l}\text { M.A., salicylic and } \\
\text { ascorbic acids } \\
\text { treatments (B) }\end{array}$} & \multicolumn{10}{|c|}{ FYM levels (ton/fed) (A) } \\
\hline & \multicolumn{5}{|c|}{$1^{\text {st }}$ season $(2013 / 2014)$} & \multicolumn{5}{|c|}{$2^{\text {nd }}$ season $(2014 / 2015)$} \\
\hline & $\mathbf{0}$ & 10 & 15 & 20 & $\begin{array}{c}\text { Mean } \\
\text { (B) }\end{array}$ & $\mathbf{0}$ & 10 & 15 & 20 & $\begin{array}{c}\text { Mean } \\
\text { (B) }\end{array}$ \\
\hline \multicolumn{11}{|c|}{ Plant height (cm) } \\
\hline M.A. at $50 \mathrm{ml} / \mathrm{l}$ & 106.2 & 111.5 & 117.5 & 122.2 & 114.3 & 111.4 & 117.1 & 123.0 & 127.9 & 119.8 \\
\hline Sal. at $50 \mathrm{ppm}$ & 103.1 & 108.3 & 113.8 & 118.3 & 110.9 & 108.4 & 113.8 & 119.5 & 124.3 & 116.5 \\
\hline Asc. at $50 \mathrm{ppm}$ & 100.4 & 105.4 & 110.8 & 115.2 & 107.9 & 104.4 & 109.6 & 115.2 & 119.9 & 112.3 \\
\hline M.A. + Sal. & 110.9 & 116.4 & 122.4 & 127.4 & 119.3 & 116.3 & 122.1 & 128.2 & 133.2 & 125.0 \\
\hline M.A. + Asc. & 108.4 & 113.8 & 119.6 & 124.4 & 116.6 & 113.8 & 119.5 & 125.5 & 130.6 & 122.4 \\
\hline Mean (A) & 105.78 & 111.09 & 116.82 & 121.51 & & 110.86 & 116.42 & 122.26 & 127.20 & \\
\hline L.S.D. at $5 \%$ & \multicolumn{2}{|c|}{ A: 4.12} & B: 3.71 & \multicolumn{2}{|c|}{ AB: 7.42} & \multicolumn{2}{|c|}{ A: 4.73} & B: 3.55 & \multicolumn{2}{|c|}{ AB: 7.10} \\
\hline \multicolumn{11}{|c|}{ Number of branches/plant } \\
\hline M.A. at $50 \mathrm{ml} / \mathrm{l}$ & 5.93 & 7.12 & 8.40 & 9.66 & 7.78 & 6.31 & 7.44 & 8.57 & 9.85 & 8.04 \\
\hline Sal. at 50 ppm & 5.71 & 6.86 & 8.09 & 9.30 & 7.49 & 5.96 & 7.05 & 8.11 & 9.30 & 7.60 \\
\hline Asc. at $50 \mathrm{ppm}$ & 5.20 & 6.24 & 7.36 & 8.46 & 6.81 & 5.37 & 6.33 & 7.28 & 8.44 & 6.86 \\
\hline M.A. + Sal. & 6.30 & 7.56 & 8.93 & 10.26 & 8.26 & 6.99 & 8.25 & 9.49 & 9.65 & 8.60 \\
\hline M.A. + Asc. & 6.02 & 7.21 & 8.52 & 9.80 & 7.89 & 6.56 & 7.74 & 8.90 & 9.61 & 8.20 \\
\hline Mean (A) & 5.83 & 7.00 & 8.26 & 9.50 & & 6.24 & 7.36 & 8.47 & 9.37 & \\
\hline L.S.D. at $5 \%$ & \multicolumn{2}{|c|}{ A: 0.61} & B: 0.55 & \multicolumn{2}{|c|}{ AB: 1.1} & \multicolumn{2}{|c|}{ A: 0.75} & B: 0.89 & \multicolumn{2}{|c|}{ AB: 1.78} \\
\hline \multicolumn{11}{|c|}{ Herb dry weight/plant (g) } \\
\hline M.A. at $50 \mathrm{ml} / \mathrm{l}$ & 35.6 & 42.6 & 50.4 & 58.0 & 46.7 & 38.0 & 44.5 & 51.3 & 59.1 & 48.2 \\
\hline Sal. at $50 \mathrm{ppm}$ & 34.2 & 41.2 & 48.5 & 55.8 & 44.9 & 35.9 & 42.4 & 48.7 & 55.7 & 45.7 \\
\hline Asc. at $50 \mathrm{ppm}$ & 31.1 & 37.5 & 44.1 & 50.8 & 40.9 & 32.2 & 38.1 & 43.8 & 50.9 & 41.3 \\
\hline M.A. + Sal. & 38.0 & 45.2 & 53.6 & 61.5 & 49.6 & 42.1 & 49.6 & 56.9 & 58.6 & 51.8 \\
\hline M.A. + Asc. & 36.2 & 43.3 & 51.1 & 58.8 & 47.4 & 39.7 & 46.6 & 54.4 & 57.6 & 49.6 \\
\hline Mean (A) & 35.03 & 41.94 & 49.54 & 56.97 & & 37.59 & 44.25 & 51.03 & 56.39 & \\
\hline L.S.D. at $5 \%$ & \multicolumn{2}{|c|}{ A: 2.21} & B: 2.40 & \multicolumn{2}{|c|}{ AB: 4.80} & \multicolumn{2}{|c|}{ A: 2.82} & B: 2.90 & \multicolumn{2}{|c|}{ AB: 5.80} \\
\hline
\end{tabular}

M.A.: Minia Azotein $\quad$ Sal.: Salicylic acid Asc.: Ascorbic acid

ton/fed in combination with M.A. + Sal. or M.A. + Asc.

\section{2- Essential oil productivity:}

Data in Table (2) indicated that essential oil percentage, oil yield/plant and oil yield/fed had significant effect of these parameters with FYM, M.A., salicylic and ascorbic acids treatments. Also, the interaction between treatments had significant effects on these traits. The highest oil percentages $(0.39 \%$ and $0.42 \%$ in the first and second seasons, respectively), oil yield/plant $(0.144$ and $0.180 \mathrm{ml}$ in both seasons, respectively) and oil yield/fed (5.749 and 7.214 liter in both seasons, respectively) were obtained at 20 ton/fed FYM Table (2). Similar results were obtained by Osman (2000), Khattab and Gomaa (2004), Abdalla (2009) and Rekaby (2013) on coriander plants. 
Table 2. Effect of FYM, Minia Azotein, salicylic and ascorbic acids on oil percentage, oil yield/plant (ml) and oil yield/fed (liter) of coriander (Coriandrum sativum, L.) plants, during the first and second seasons.

\begin{tabular}{|c|c|c|c|c|c|c|c|c|c|c|}
\hline \multirow{3}{*}{$\begin{array}{l}\text { M.A., salicylic and } \\
\text { ascorbic acids } \\
\text { treatments (B) }\end{array}$} & \multirow{2}{*}{\multicolumn{10}{|c|}{ FYM levels (ton/fed) (A) }} \\
\hline & \multicolumn{5}{|c|}{$1^{\text {st }}$ season $(2013 / 2014)$} & \multicolumn{4}{|c|}{$2^{\text {nd }}$ season $(2014 / 2015)$} & \\
\hline & $\mathbf{0}$ & 10 & 15 & 20 & $\begin{array}{c}\text { Mean } \\
\text { (B) }\end{array}$ & $\mathbf{0}$ & 10 & 15 & 20 & $\begin{array}{c}\text { Mean } \\
\text { (B) }\end{array}$ \\
\hline \multicolumn{11}{|c|}{ Oil percentage } \\
\hline M.A. at $50 \mathrm{ml} / \mathbf{l}$ & 0.28 & 0.30 & 0.33 & 0.36 & 0.32 & 0.28 & 0.33 & 0.34 & 0.37 & 0.33 \\
\hline Sal. at $50 \mathrm{ppm}$ & 0.30 & 0.33 & 0.36 & 0.39 & 0.35 & 0.35 & 0.36 & 0.42 & 0.43 & 0.39 \\
\hline Asc. at $50 \mathrm{ppm}$ & 0.30 & 0.33 & 0.35 & 0.38 & 0.34 & 0.33 & 0.35 & 0.39 & 0.40 & 0.37 \\
\hline M.A. + Sal. & 0.32 & 0.35 & 0.38 & 0.41 & 0.37 & 0.34 & 0.39 & 0.43 & 0.46 & 0.40 \\
\hline M.A. + Asc. & 0.32 & 0.34 & 0.36 & 0.40 & 0.36 & 0.33 & 0.37 & 0.42 & 0.46 & 0.39 \\
\hline Mean (A) & 0.30 & 0.33 & 0.35 & 0.39 & & 0.32 & 0.36 & 0.40 & 0.42 & \\
\hline L.S.D. at 5 \% & \multicolumn{2}{|c|}{ A: 0.02} & B: 0.01 & \multicolumn{2}{|c|}{ AB: 0.02} & \multicolumn{2}{|l|}{ A: 0.03} & B: 0.01 & \multicolumn{2}{|c|}{ AB: 0.02} \\
\hline \multicolumn{11}{|c|}{ Oil yield/plant (ml) } \\
\hline M.A. at $50 \mathrm{ml} / \mathbf{l}$ & 0.046 & 0.067 & 0.098 & 0.131 & 0.083 & 0.053 & 0.082 & 0.116 & 0.153 & 0.098 \\
\hline Sal. at 50 ppm & 0.046 & 0.067 & 0.078 & 0.134 & 0.080 & 0.059 & 0.083 & 0.132 & 0.165 & 0.107 \\
\hline Asc. at 50 ppm & 0.042 & 0.061 & 0.087 & 0.117 & 0.075 & 0.049 & 0.071 & 0.109 & 0.138 & 0.090 \\
\hline M.A. + Sal. & 0.059 & 0.088 & 0.130 & 0.173 & 0.111 & 0.075 & 0.117 & 0.175 & 0.230 & 0.143 \\
\hline M.A. + Asc. & 0.055 & 0.080 & 0.120 & 0.163 & 0.103 & 0.067 & 0.103 & 0.160 & 0.215 & 0.129 \\
\hline Mean (A) & 0.050 & 0.073 & 0.102 & 0.144 & & 0.060 & 0.091 & 0.138 & 0.180 & \\
\hline L.S.D. at $5 \%$ & \multicolumn{2}{|c|}{ A: 0.021} & B: 0.008 & \multicolumn{2}{|c|}{ AB: 0.016} & \multicolumn{2}{|c|}{ A: 0.028} & B: 0.011 & \multicolumn{2}{|c|}{ AB: 0.022} \\
\hline \multicolumn{11}{|c|}{ Oil yield /fed (liter) } \\
\hline M.A. at $50 \mathrm{ml} / \mathrm{l}$ & 1.844 & 2.701 & 3.891 & 5.240 & 3.308 & 2.103 & 3.293 & 4.602 & 6.149 & 3.904 \\
\hline Sal. at $50 \mathrm{ppm}$ & 1.841 & 2.685 & 3.121 & 5.364 & 3.192 & 2.357 & 3.310 & 5.278 & 6.598 & 4.270 \\
\hline Asc. at $50 \mathrm{ppm}$ & 1.667 & 2.431 & 3.501 & 4.678 & 2.976 & 1.980 & 2.875 & 4.370 & 5.482 & 3.617 \\
\hline M.A. + Sal. & 2.370 & 3.543 & 5.203 & 6.937 & 4.451 & 2.967 & 4.678 & 7.001 & 9.216 & 5.694 \\
\hline M.A. + Asc. & 2.179 & 3.172 & 4.807 & 6.526 & 4.121 & 2.676 & 4.122 & 6.369 & 8.625 & 5.174 \\
\hline Mean (A) & 1.980 & 2.906 & 4.104 & 5.749 & & 2.417 & 3.655 & 5.524 & 7.214 & \\
\hline L.S.D. at $5 \%$ & \multicolumn{2}{|c|}{ A: 0.311} & B: 0.315 & \multicolumn{2}{|c|}{ AB: 0.630} & A: 0.375 & & B: 0.322 & \multicolumn{2}{|c|}{ AB: 0.644} \\
\hline
\end{tabular}

M.A.: Minia Azotein Sal.: Salicylic acid Asc.: Ascorbic acid

Mean comparison for M.A., salicylic and ascorbic acids treatments showed that M.A. plus either Sal. or Asc. gave the highest essential oil \%, oil yield/plant and /fed (Table, 2).

The combination treatments between FYM (20 ton/fed) and M.A.+ Sal. or M.A. + Asc. gave the highest values in both seasons.

\section{DISCUSSION}

The obtained results indicated the favorable effect of FYM on coriander plant growth and productivity. Organic fertilizer improves the soil texture. The structural improvement can encourage the plant to have a good root development by improving the aeration in the soil, which leads to a higher plant growth. Also, the obtained 
results indicated the favorable effect of FYM on coriander plant productivity, this result might be due to the role of organic material for continues supply of nutrients, growth stimulants, disease suppressors and support biologically diverse and metabolically dynamic process during the plant growth plays an essential role in the biosynthesis of the organic substances (Weltzien, 1990 and Fliessbach et al., 2000).

Minia Azotein as biofertilizer contain a mixture of Azotobacter strain of bacteria which increase crop growth through different mechanisms, i.e. biological nitrogen fixation, growth-promoting or hormonal substances increasing availability of soil nutrients (Galal and Aly, 2004)

Salicylic acid is a naturally occurring phenolic compound found in many plants. As an important endogenous signal molecule, salicylic acid has been proven to be a major component in signal molecule transduction systems, which can induce particular enzymes catalyzing biosynthetic reactions and is essential for the development of systematic acquired resistance (Klessig and Malamy, 1994). It is assigned divers regulatory role in the metabolism of plants (Raskin, 1992 and Popova et al., 1997). Salicylic acid has direct involvement in plant growth, thermogenesis, lower induction and uptake of ions (Gorddon et al., 1997; Dat et al., 2000).

Generally, the physiological effects of ascorbic acid include stimulation of respiration, photosynthesis cell division, manage enzymes activities, promotion of lipase, catalase, as well as, increase vegetative growth and oil \% (Oertli, 1987; Dewick, 2000).

\section{REFERENCES}

Abd El-Latif, M.T.M. (2014). Physiological Studies on Lavandula officinalis Plants Ph.D. Thesis, Fac. Agric. Minia Univ., Egypt.

Abdalla, M.Y.A. (2009). Effect of organic, bio and mineral fertilization on growth, yield, oil productivity and chemical constituents of coriander plant. J. Agric. Sci. Mansoura Univ., 34(5):5195-5208.

Abdou, M.A.H.; Abdalla, M.Y.; Helaly, A. and Mosaad, S. (2012). Physiological studies on sage plant. Minia J. of Agric. Res. \& Develop., 32(2):161-186.

Abdou, M.A.H.; Aly, M.K.; Zaki, K.A.; Sadek, A.A. and El-Husseiny, R. (2009a). Response of borage plants to some organic and biofertilization treatments. Proc. $5^{\text {th }}$ of Sustain, Agric. and Develop. Fac. Agric., Fayoum Univ., 21-23 December, pp:143-158.

Abdou, M.A.H.; Attia, F.A.; Ahmed, E.T. and Abd El-Naeem, L. (2009b). Response of caraway plants to some organic, antioxidants and biofertilization treatments. Proc. $4^{\text {th }}$ Inter. Environ. Conf., Mansoura Univ. on Environmental and Healthy Safety, p: 109-119.

Abdou, M.A.H.; El-Sayed, A.A.; Taha, R.A. and Botros, W.S. (2013). Physiological studies on caraway plants. Proc. $1^{\text {st }}$ Inter. Conf. of Hort. Agric. Assuit, February 2013.

Abdou, M.A.H.; Hamed, A.N.E.; El-Sayed, A.A.; Ahmed, E.T. and Ibrahim, T.I.E. (2014). Effect of some clean agricultural treatments on fruit yield, active ingredients and chemical composition of Ammi visnaga, L. Minia J. of Agric. Res. \& Develop., 34(1):1-12.

Al-Shareif, A.M.O. (2006). Response of Caraway Plants Grown in Sandy Soil Under Drip Irrigation System to Some Biofertilization and Antioxidant Treatments. M.Sc. Thesis., Fac. Agric., Minia Univ., Egypt.

Al-Shewailly, M.R. (2012). Physiological study of the effect planting method and number of plant in hill and spraying of salicylic acid on vegetative and growth of cumin plant (Cuminum cyminum, L.). Basrah J. Agric. Sci., 25(2):37-46.

Ayat, A.M. (2007). Effect of Fertilization with Macro, Micro Nutrients and 
Antioxidants on Coriander (Coriandrum sativum, L.) Plants Grown in New Reclaimed Land. M.Sc. Thesis, Fac. Agric., Minia Univ., Egypt.

Botros, W.S.E. (2013). Physiological Studies on Caraway Plants. M.Sc. Thesis, Fac. Agric., Minia Univ., Egypt.

Dat, J.F.; Lopez-Delgado, H.; Foyer, C.H. and Scott, I.M. (2000). Effect of salicylic acid on oxidative stress and thermtolerance on tobacco. J. Pl. physiol., 156:659-665.

Dewick, P.M. (2000). Medicinal Natural Products. A Biosynthetic Approach $2^{\text {nd }}$ Ed., John Wiley and Sons, N.Y., 306356.

Fliessbach, A., Mader, P., Dubois, D. and Gunst, L. (2000). Results from 21 years old field trial. Organic farming enhances soil fertility and biodiversity. Bulletin Research of Organic Agriculture, 1, 1519.

Galal, Y.G.M. and Aly, B.E. (2004). II: Biofertilization and Organic Farming Approaches, Advance in Agricultural Research in Egypt. Special Issue Vol. S, N. 1. p. 99-176. Published by the Agricultural Research Center, Giza, Egypt.

Gorddon, L.K.; Minibayeva, F.V.; Ogerodnikova, I.I.; Rackhmatulina, D.F.; Tzentzevitzky, A.N.; Maksyntin, D.A. and Calitova, J.N. (1997). Salicylic acid induced dissipation the portion gradient on the plant cell membranes. Doklady Biol. Sci., 387:581-583.

Hassan, E.A. and Ali, E.F. (2010). Response of Coriandrum sativum, L. plants to cutting, as well as, glycine and salicylic acid treatments. Minia J. of Agric. Res. \& Dev., 30(1):15-29.

Helmy, T.A. (2008). Effect of Some Organic and Biofertilization Treatments on Black Cumin Plants. M.Sc. Thesis, Fac. Agric., Minia Univ., Egypt.
Hemdan, S.H.O. (2008). Effect of Some Organic and Biofertilization Treatments on Anise Plants. M.Sc. Thesis, Fac. Agric. Minia Univ.

Hendawy, S.F. and Ezz El-Din, A.A. (2010). Growth and yield of Foeniculum vulgare, var. Azoricum as influenced by some vitamins and amino acids. Ozean Journal of Applied Sciences, 3(1):113-123.

Ibrahim, T.I.E. (2014). Influence of Some Agricultural Treatments on Ammi visnaga, Plants. Ph.D. Thesis, Fac. Agric., Minia Univ., Egypt.

Ismail, S.I.I. (2008). Anatomical and Physiological Studies on Nigella sativa, L. Plant. Ph.D. Thesis, Fac. Agric., Mansoura Univ., Egypt.

Khattab, M.E. and Gomaa, A.M. (2004). Yield and essential oil quality of coriander as influenced by chicken manure, rock phosphate, sulfur and phosphate solubilizing Bacillus treatments. J. Agric. Sci., Mansoura Univ., 29(9):5231-5244.

Klessig, D.F. and Malamy, J. (1994). The salicylic acid signal in plants. Plant Mol. Biol., 26:1439-1458.

MSTAT-C (1986). A Microcomputer Program for the Design, Management and Analysis of Agronomic Research Experiments (Version 4.0), Michigan Stat Univ., U.S.

Oertli, J.J. (1987). Exogenous application of vitamins as regulators for growth and development of plant. A review Z. planzenernahr. Bodenk., 150:375-391.

Osman, Y.A. (2000). The Possibility of Production of Coriander (Coriandrum sativum, L.) Under Sinai Conditions. Ph.D. Thesis, Fac. Agric., Cairo Univ., Egypt.

Popova, I.; Pancheva, T. and Uzunova, A.; (1997). Salicylic acid: properties, biosynthesis and physiological role, Bulg. J. Plant Physiolg., 23:85-93. 
Rahimi, A.R.; Rokhzadi, A.; Amini, S. and Karami, E. (2013). Effect of salicylic acid and methyl jasmonate on growth and secondary metabolites in Cuminum cyminum, L.. Journal of Biodiversity and Environmental Sciences, 3(12):140-149.

Raskin, I. (1992). Salicylate, a new plant hormone. Plant physiology., 99:799-803.

Rekaby, A.M. (2013). Improving The Productivity of Coriander Plants by The Use of Some Unconventional Treatments. Ph.D. Thesis, Fac. Agric., Minia Univ., Egypt.

Shala, A.Y.E. (2012). Response of Foeniculum vulgare, Mill. and Carum carvi, L. to NPK and Ascorbic and Salicylic Acids Treatments. Ph.D. Thesis, Fac. Agric., Kafr El-Sheikh Univ., Egypt.

Shoor, M.; Khalesi, N.; Kazemi, M.S. and Yazdi, K. (2010). Effect of organic manure and nitrogen fertilizer on yield, essence and extract of black cumin (Nigella sativa, L.). Abstract in the Proceeding of the International Medicinal and Aromatic Plants Symposium, June 21-23, Shiraz, Iran.

Stary, F. and Jirasck, V. (1975). A Concise Guide in Color Herbs. Hamlin, London, New York, Sydney, Toronto.

Tanious, C.T.S. (2008). Effect of Some Organic Fertilization Treatments on Fennel Plants. M.Sc. Thesis, Fac. Agric., Minia Univ., Egypt.

Weltzien, H.C. (1990). The use of composted material for leaf disease suppression in field crop. Monograph of Organic Farming, 45:115-121.

\section{تأثير معســـلات السماد العضوي و السماد الحيوي المنيا أزوتين وحمضي السـاليساليك والأسكوربيك

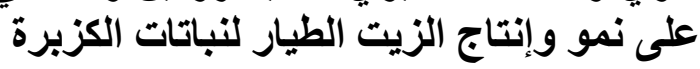

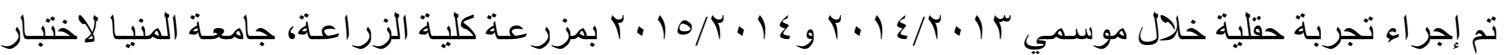

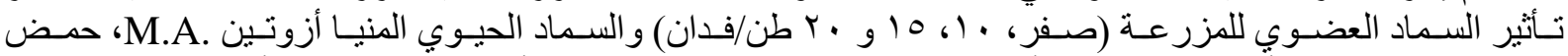

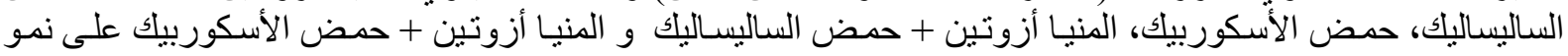
و إنتاجية الزيت الطبار للكزبرة.

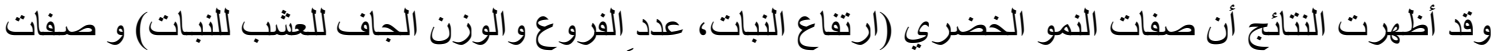

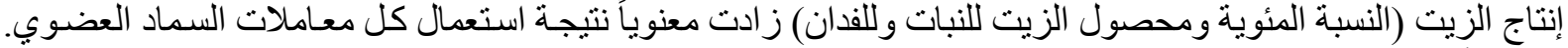

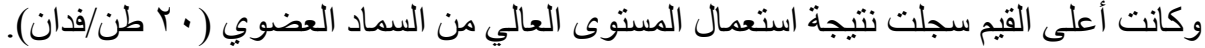

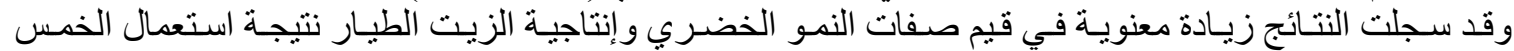

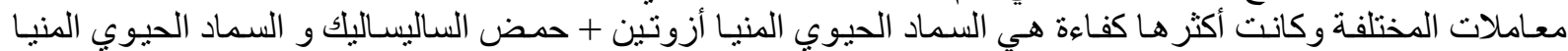

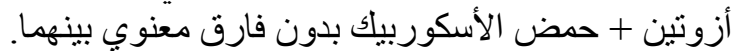

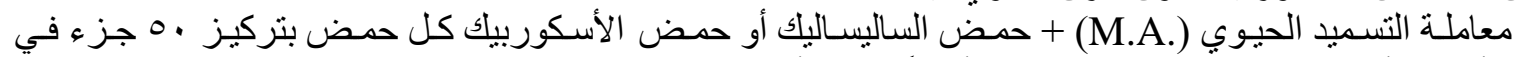
المليون أعطت أعلى نسبة مئوية للزيت الطيار و أيضاً سجلت أعلى محصول زيت الئ طيار للنبات.

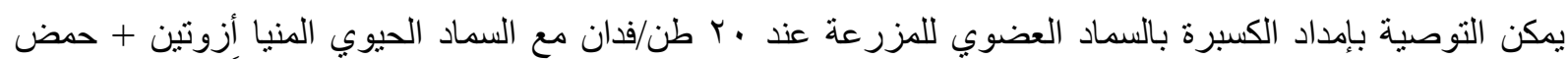

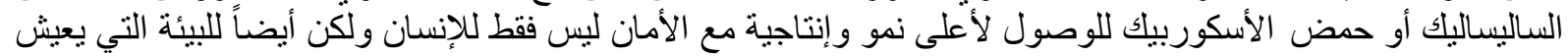
فيها الإنسان. 